\title{
Transgenic overexpression of human islet amyloid polypeptide inhibits insulin secretion and glucose elimination after gastric glucose gavage in mice
}

\author{
B. Ahrén ${ }^{1}$, C. Oosterwijk ${ }^{2,3}$, C.J.M. Lips ${ }^{2}$, J.W.M. Höppener ${ }^{2,3}$ \\ ${ }^{1}$ Department of Medicine, Lund University, Malmö, Sweden \\ ${ }^{2}$ Department of Internal Medicine, Utrecht University, Utrecht, The Netherlands \\ ${ }^{3}$ Department of Pathology, Utrecht University, Utrecht, The Netherlands
}

\begin{abstract}
Summary Islet amyloid polypeptide (IAPP) is synthesized in islet beta cells and has been implicated in diabetes pathogenesis because it can inhibit insulin secretion and action and form fibrils leading to islet amyloidosis. Its physiological function has, however, not been established. We therefore examined insulin secretion and glucose elimination after i.v. or gastric gavage of glucose in transgenic mice overexpressing human IAPP (hIAPP) resulting in considerably increased circulating IAPP concentrations. The insulin response to and the glucose elimination after i.v. glucose $(1 \mathrm{~g} / \mathrm{kg})$ were not different in transgenic mice compared with wild type animals, neither in males nor in females. In contrast, the insulin response to gastric glucose $(150 \mathrm{mg} / \mathrm{mouse})$ was reduced and the glucose elimination was inhibited in both male and female transgenic mice. The area under the $30 \mathrm{~min}$ insulin curve $\left(\mathrm{AUC}_{\text {insulin }}\right)$ was $21 \pm 2 \mathrm{nmol} / \mathrm{l}$ in $30 \mathrm{~min}$
\end{abstract}

in transgenic males $(n=24)$ vs $43 \pm 3 \mathrm{nmol} / 1$ in $30 \mathrm{~min}$ in wild type males $(n=26 ; p<0.001)$ and the respective areas under the glucose curve $\left(\mathrm{AUC}_{\text {glucose }}\right)$ were $1.90 \pm 0.12$ and $1.62 \pm 0.09 \mathrm{~mol} / 1$ in $120 \mathrm{~min}$ $(p<0.05)$. Similarly, in females, the $\mathrm{AUC}_{\text {insulin }}$ was $17 \pm 2 \mathrm{nmol} / \mathrm{l}$ in $30 \mathrm{~min}$ in transgenic mice vs $25 \pm 3$ $\mathrm{nmol} / \mathrm{l}$ in $30 \mathrm{~min}$ in wild type mice $(p<0.05)$ and the respective $\mathrm{AUC}_{\text {glucose }}$ was $1.62 \pm 0.7$ and $1.12 \pm$ $0.07 \mathrm{~mol} / \mathrm{l}$ in $120 \mathrm{~min}(p<0.001)$. Hence, endogenous hIAPP inhibits insulin secretion and glucose elimination after gastric glucose gavage in both male and female mice, indicating that overexpression of hIAPP could be a diabetogenic factor, via effects on the intestinal tract or the gut-islet axis or both. [Diabetologia (1998) 41: 1374-1380]

Keywords IAPP, amylin, insulin secretion, glucose elimination, glucose tolerance, transgenic mice
Islet amyloid polypeptide (IAPP, also designated amylin) is a 37 amino acid polypeptide which is synthesized in islet beta cells and co-stored and co-released with insulin [1-6]. Exogenous treatment with the peptide inhibits insulin secretion in the perfused rat pancreas [7], in isolated rat islets [8, 9] and in vivo in rats [10] and humans [11], and a specific IAPP antagonist increases insulin secretion from islets [12]. It has also been shown that IAPP

Received: 31 March 1998 and in revised form: 15 June 1998

Corresponding author: Dr. B. Ahrén, Department of Medicine, Malmö University Hospital, S-205 02 Malmö, Sweden Abbreviations: IAPP, Islet amyloid polypeptide; hIAPP, human IAPP; AUC, area under the curve; $\mathrm{AIR}_{\mathrm{G}}$, acute insulin response to glucose; $\mathrm{K}_{\mathrm{G}}$, glucose elimination rate. inhibits glycogen formation in skeletal muscle [13] and induces insulin resistance in rats $[14,15]$. This would suggest it inhibits both insulin secretion and action and, consequently, if overexpressed in a prediabetic stage, could add to the pathogenesis of Type II (non-insulin-dependent) diabetes mellitus. It has, however, also been claimed that IAPP does not impair insulin secretion $[16,17]$ or insulin sensitivity [18]. Therefore, its physiological function is not yet established. In addition to its putative physiological actions, IAPP is also of interest in diabetes pathogenesis due to its ability to form fibrils, which are constituents of the islet amyloid characteristically accompanying Type II diabetes $[19,20]$.

To study the physiological function of IAPP as a circulating peptide, transgenic mice overexpressing 
human IAPP (hIAPP) were generated previously [21]. It was found, that although plasma IAPP was considerably increased in these mice over a long period of time and the synthesized IAPP is biologically active [22], concentrations of circulating insulin and glucose were not altered [21]. One interpretation of this finding is that IAPP has no physiological impact on insulin secretion or glucose homeostasis. Another is that measuring a random blood sample for the determination of insulin and glucose is not adequate to detect any physiological function of the peptide in this respect. Other transgenic mouse strains overexpressing hIAPP have been shown to display hyperglycaemia in a subset of the mice after 2 months in homozygotic transgenic animals [23] or after 6 months on a diet causing obesity [24]. Since islet amyloid had developed in these latter mouse strains, it is, however, possible that the amyloid deposits had influenced islet function. Therefore, it was still not established whether endogenous hyperhIAPPaemia per se affects insulin secretion and glucose metabolism.

In this study, we have undertaken both intravenous and gastric glucose tolerance tests in homozygous hIAPP transgenic mice at an age of 2 to 3 months, when no islet amyloid formation was evident. The intravenous glucose tolerance test in anaesthetized mice with multiple blood sampling produced information both on glucose-stimulated insulin secretion and glucose elimination. In addition, the gastric glucose tolerance test provided an insight into whether IAPP affects the complexly regulated insulin secretion after gastric glucose, which involves gastric emptying, glucose absorption and the release and action of gut hormones.

\section{Materials and methods}

Animals. Human IAPP overproducing transgenic mice were generated as described previously [21]. The transgenic lines were maintained by breeding heterozygous transgenic mice with mates of the $\mathrm{C} 57 \mathrm{BL} / 6 \mathrm{~J}$ strain. Homozygous transgenic mice were obtained by breeding heterozygous transgenic mice. They were differentiated from heterozygous transgenic mice and wild type littermates by dot blot Southern hybridization, using a $588 \mathrm{bp}$ hIAPP specific cDNA probe [21] and measurement of the hybridization signal, using phosphor-imaging and ImageQuant software (Molecular Dynamics, Inc. $\mathrm{GmbH}$, Krefeld, Germany). To exclude effects related to the integration site of the transgene DNA construct in the mouse genomic DNA ("position effect"), which might become evident particularly in homozygotic transgenic mice, hIAPP transgenic mice from two different lines (no 14 and no 18) were used for the experiments. The mice were housed on hardwood bedding in polypropylene cages and maintained in air-conditioned rooms at $20-22^{\circ} \mathrm{C}$ with a photoperiod of $12 \mathrm{~h}$ light, $12 \mathrm{~h}$ dark. Water and commercial mouse diet (RMH-TM, Hope Farms, Woerden, The Netherlands) were available continuously. When the mice were 7-12 weeks of age, intravenous or gastric glucose tolerance tests were carried out.
Intravenous glucose tolerance test. At the age of 7 weeks (means \pm SD $7.2 \pm 1.8$ weeks), 20 transgenic males, 14 wild type males, 24 transgenic females and 20 wild type females underwent an intravenous glucose tolerance test. In 8 transgenic males, 8 wild type males, 11 transgenic females and 10 wild type females, the intravenous glucose tolerance test was repeated at the age of 12 weeks (means \pm SD $12.0 \pm 0.1$ weeks). In the test, non-fasted mice were anaesthetized with an i.p. injection of midazolam (Dormicum, Hoffman-La-Roche, Basel, Switzerland, $0.4 \mathrm{mg} / \mathrm{mouse})$ and a combination of fluanison $(0.9 \mathrm{mg} /$ mouse) and fentanyl (0.02 mg/mouse; Hypnorm, Janssen, Beerse, Belgium). This mode of anaesthesia has been found to result in stable anaesthesia without influencing baseline values of glucose or insulin (data not shown). The intravenous glucose tolerance test with the use of this anaesthesia has been described recently [25]. After the induction of anaesthesia, a blood sample was taken from the retrobulbar, intraorbital, capillary plexus, then D-glucose (British Drug Houses, Poole, UK; $1 \mathrm{~g} / \mathrm{kg}$ ) was injected rapidly and intravenously into a tail vein. The volume load was $10 \mu \mathrm{l} / \mathrm{g}$ body weight. New blood samples were taken after 1, 7, 20 and 50 min. The samples were taken in heparinized tubes and stored on ice. After centrifugation, plasma was separated and stored at $-20^{\circ} \mathrm{C}$ until analysis.

Gastric glucose tolerance test. At the age of 11 weeks (means \pm SD $10.6 \pm 3.8$ weeks), 24 transgenic males, 26 wild type males, 25 transgenic females and 23 wild type females were fasted overnight and anaesthetized with an i.p. injection of midazolam (Dormicum, $0.4 \mathrm{mg} / \mathrm{mouse}$ ) and a combination of fluanison ( $0.9 \mathrm{mg} / \mathrm{mouse})$ and fentanyl $(0.02 \mathrm{mg} / \mathrm{mouse}$; Hypnorm). Of the mice, 18 transgenic males, 14 wild type males, 22 transgenic females and 19 wild type females had undergone the intravenous glucose tolerance test 3 weeks before. After induction of anaesthesia, a blood sample was taken from the retrobulbar, intraorbital, capillary plexus, then D-glucose $(150 \mathrm{mg} / \mathrm{mouse}$ in $0.5 \mathrm{ml}$ ) was given through a gavage tube (outer diameter $1.2 \mathrm{~mm}$ ) placed in the stomach. New blood samples were taken after 10, 30,60 and $120 \mathrm{~min}$. The samples were taken in heparinized tubes and stored on ice. Following centrifugation, plasma was separated and stored at $-20^{\circ} \mathrm{C}$ until analysis.

Blood sampling. At the time of killing (at $17.7 \pm 4.7$ weeks (means \pm SD), range 9.8-25.1 weeks), trunk blood from nonfasted or overnight fasted mice was collected in EDTA tubes, plasma was collected by centrifugation at $4{ }^{\circ} \mathrm{C}$ for $5 \mathrm{~min}$ at $3000 \mathrm{rpm}$ and stored at $-80^{\circ} \mathrm{C}$ until used in the determination of IAPP.

Analyses. Plasma insulin was determined radioimmunochemically with the use of a guinea pig anti-rat insulin antibody, ${ }^{125}$ I-labelled porcine insulin as tracer and rat insulin as standard (Linco Research, St Charles, Mo., USA). Free and bound radioactivity was separated by use of an anti-IgG (goat antiguinea pig) antibody (Linco). The sensitivity of the assay is 12 $\mathrm{pmol} / \mathrm{l}$ and the coefficiency of variation is less than $3 \%$. Plasma IAPP immunoreactivity was measured by radioimmunoassay using human IAPP antiserum K1338, which cross reacts with synthetic rat IAPP [26]. Free and bound radioactivity was separated by use of double antibody immunoprecipitation. The sensitivity of the assay is $3.5 \mathrm{fmol} / \mathrm{l}$ and the coefficiency of variation is less than $15 \%$ at plasma IAPP levels exceeding 28 $\mathrm{pmol} / \mathrm{l}$. Plasma glucose was determined with the glucose oxidase method.

Congo red staining of pancreas. To detect islet amyloid deposits, specimens of pancreas were obtained at the time of killing. The specimens were fixed in $4 \%$ phosphate-buffered formalin 
Table 1. Plasma concentrations of IAPP at time of killing (at on average 18 weeks of age, $n$ indicates number of animals) in hIAPP transgenic mice and wild type littermates of both sexes. Probability level of random difference between transgenic and wild type mice; $* * * p<0.001$

\begin{tabular}{lll}
\hline & Transgenic & Wild type \\
\hline Non-fasted males & $351 \pm 88(n=11)^{* * *}$ & $38 \pm 4(n=20)$ \\
Non-fasted females & $160 \pm 29(n=6)^{* * *}$ & $12 \pm 3(n=7)$ \\
Fasted males & $166 \pm 43(n=8)^{* * *}$ & $31 \pm 3(n=5)$ \\
Fasted females & $281 \pm 32(n=23)^{* * *}$ & $8 \pm 0(n=21)$ \\
\hline
\end{tabular}

( $\mathrm{pH}$ 7.4) for $24 \mathrm{~h}$ and paraffin embedded. Congo red stained sections were examined by polarized light microscopy, which reveals an "applegreen" birefringence of amyloid deposits [27].

Statistics. Means \pm SEM are shown. Statistical analyses were done with the SPSS for Windows system. Statistical comparisons between groups were done with the Mann-Whitney Utest. The suprabasal areas under the curve (AUC) for insulin $\left(\mathrm{AUC}_{\text {insulin }}\right)$ and glucose $\left(\mathrm{AUC}_{\mathrm{glucose}}\right)$ were assessed using the trapezoidal rule of suprabasal values. In the intravenous glucose tolerance test, the acute insulin response to glucose $\left(\mathrm{AIR}_{\mathrm{G}}\right)$ was calculated by subtracting the baseline insulin levels from the mean of the 1 and 7 min insulin values. The glucose elimination rate after the glucose injection $\left(\mathrm{K}_{\mathrm{G}}\right)$ was calculated using the $t_{1 / 2}$ for min 1-20 after glucose injection after logarithmic transformation of the individual plasma glucose values.

\section{Results}

Body weight, age and baseline plasma concentrations of IAPP, insulin and glucose. Plasma concentrations of IAPP were considerably increased in hIAPP transgenic mice (Table 1) but no difference was seen between the transgenic lines no 14 and no 18 , neither under non-fasted conditions $(224 \pm 36(n=10)$ vs $369 \pm 139(n=7) \mathrm{pmol} / \mathrm{l})$ nor under fasted conditions $(216 \pm 25(n=18)$ vs $301 \pm 54(n=13) \mathrm{pmol} / \mathrm{l})$. There were no significant differences in body weight or age at the time of the experiments between transgenic and wild type mice (Table 2). There were also no significant differences in baseline plasma concentrations of insulin and glucose in hIAPP transgenic versus wild type mice under non-fasted or fasted conditions in females or males, except a slight increase in plasma insulin concentrations in non-fasted hIAPP transgenic females $(p=0.002)$ and in plasma glucose concentrations in fasted hIAPP transgenic females $(p=0.016$, Figs. 1,2)

Intravenous glucose tolerance tests. Intravenous glucose tolerance tests were done on 7- and 12-weekold mice. There were no significant differences in any of the determined variables between these two tests. Therefore, the results from the two were pooled. It was found that both in males and females,
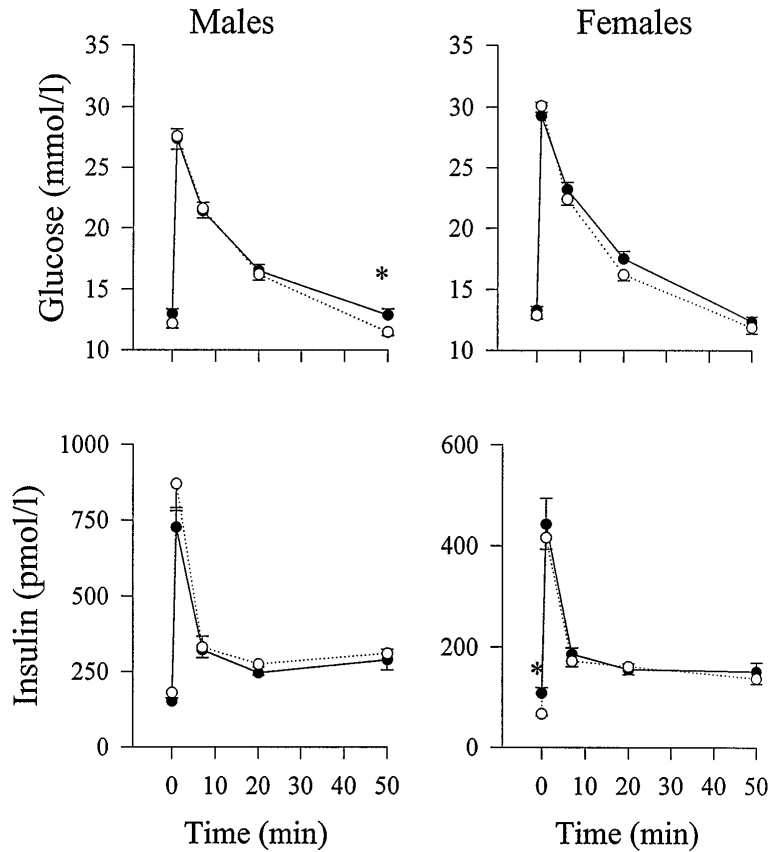

Fig. 1. Plasma glucose and insulin concentrations immediately before and at 1, 7, 20 and 50 min after an i.v. injection of glucose $(1 \mathrm{~g} / \mathrm{kg})$ in anaesthetized hIAPP transgenic or wild type mice. Means \pm SEM are shown. The results are compiled of the following number of intravenous glucose tolerance tests: 28 tests in 20 transgenic males, 22 tests in 14 wild type males, 35 tests in 24 transgenic females, and 30 tests in 20 wild type females. The experiments were done when the mice were on average 7 weeks of age $(n=78$; means \pm SD $7.2 \pm 1.8$ weeks of age $)$ or 12 weeks $(n=37$; means \pm SD $12.0 \pm 0.1$ weeks of age). Probability level of random difference between the groups; ${ }^{*} p<0.05 \bullet$ hIAPP transgenic mice, $\bigcirc---\bigcirc$ indicates wild type mice

the increase in plasma insulin after the rapid intravenous glucose challenge was the same in hIAPP transgenic and wild type mice, both when calculated as the delta increase in plasma insulin at 1 min after glucose injection, the $\mathrm{AIR}_{\mathrm{G}}$, as well as the $\mathrm{AUC}_{\text {insulin }}$ for the entire $50 \mathrm{~min}$ period. Similarly, the glucose elimination was not significantly different in transgenic compared with wild type animals of both sexes, when calculated as individual values at each time point, as $\mathrm{AUC}_{\text {glucose }}$ for the entire $50 \mathrm{~min}$ time period, or as the $K_{G}$ values, which are calculated for min 1-20 after glucose was given. The only difference observed was a slightly higher plasma glucose at $50 \mathrm{~min}$ after intravenous glucose in transgenic males compared with wild type males ( $p=0.029$ ) (Fig. 1, Table 2). No difference in the variables obtained during the intravenous glucose tolerance test was observed between hIAPP transgenic lines no 14 and no 18 (data not shown separately).

Gastric glucose tolerance test. The gastric glucose tolerance tests were done when the mice were at the age of 11 weeks. Plasma glucose increased to a simi- 
Table 2. Body weight, $\mathrm{AIR}_{\mathrm{G}}, \mathrm{AUC}_{\text {insulin }}$, and $\mathrm{AUC}_{\text {glucose }}$ and the $\mathrm{K}_{\mathrm{G}}$ level after giving glucose intravenously (intravenous glucose tolerance test; IVGTT) or by gastric gavage (gastric glucose tolerance test; GGTT) in hIAPP transgenic or nontransgenic male or female mice. The mice were 7-12 weeks old in the intravenous test and on average 11 weeks old in the gastric test. Probability level of random difference between transgenic and wild type mice, $* p<0.05$, ** $p<0.01$, $* * * p<0.001$

\begin{tabular}{|c|c|c|c|c|}
\hline & \multicolumn{2}{|l|}{ Males } & \multicolumn{2}{|l|}{ Females } \\
\hline & Transgenic & Wild type & Transgenic & Wild type \\
\hline $\begin{array}{l}\text { IVGTT } \\
\text { Number of animals (number of tests) } \\
\text { body weight }(\mathrm{g}) \\
\mathrm{AIR}_{\mathrm{G}}(\mathrm{pmol} / \mathrm{l}) \\
\Delta_{\text {insulin } 1 \text { min }}(\mathrm{pmol} / \mathrm{l}) \\
\mathrm{AUC}_{\mathrm{insulin}}(\mathrm{nmol} / \mathrm{l} \text { in } 50 \mathrm{~min}) \\
\mathrm{K}_{\mathrm{G}}(\% / \mathrm{minute}) \\
\text { AUC }_{\text {glucose }}(\mathrm{mmol} / \mathrm{l} \text { in } 50 \mathrm{~min})\end{array}$ & $\begin{array}{l}20(28) \\
25.5 \pm 0.7 \\
371 \pm 38 \\
573 \pm 66 \\
7.7 \pm 0.8 \\
2.1 \pm 0.1 \\
220 \pm 12\end{array}$ & $\begin{array}{l}14(22) \\
26.4 \pm 0.7 \\
419 \pm 26 \\
689 \pm 83 \\
8.3 \pm 1.2 \\
2.1 \pm 0.1 \\
205 \pm 28\end{array}$ & $\begin{array}{l}24(35) \\
20.4 \pm 0.4 \\
206 \pm 22 \\
334 \pm 43 \\
4.6 \pm 0.5 \\
2.1 \pm 0.1 \\
232 \pm 19\end{array}$ & $\begin{array}{l}20(30) \\
20.0 \pm 0.5 \\
227 \pm 14 \\
348 \pm 22 \\
5.5 \pm 0.5 \\
2.3 \pm 0.1 \\
201 \pm 23\end{array}$ \\
\hline $\begin{array}{l}\text { GGTT } \\
\text { number of animals and tests } \\
\text { body weight }(\mathrm{g}) \\
\Delta_{\text {insulin } 10 \mathrm{~min}}(\mathrm{pmol} / \mathrm{l}) \\
\Delta_{\text {insulin } 30 \mathrm{~min}}(\mathrm{pmol} / \mathrm{l}) \\
\mathrm{AUC}_{\text {insulin } 30 \mathrm{~min}}(\mathrm{nmol} / \mathrm{l} \text { in } 30 \mathrm{~min}) \\
\mathrm{AUC}_{\text {insulin } 120 \mathrm{~min}}(\mathrm{nmol} / \mathrm{l} \text { in } 120 \mathrm{~min}) \\
\Delta_{\text {glucose } 10 \mathrm{~min}}(\mathrm{mmol} / \mathrm{l}) \\
\mathrm{AUC}_{\text {glucose }}(\mathrm{mol} / \mathrm{l} \mathrm{in} 120 \mathrm{~min})\end{array}$ & $\begin{array}{l}24 \\
23.1 \pm 0.7 \\
446 \pm 77^{* * *} \\
1434 \pm 135^{* * *} \\
21.0 \pm 2.1^{* * *} \\
72.1 \pm 5.6^{* * *} \\
25.2 \pm 1.6 \\
1.90 \pm 0.12 *\end{array}$ & $\begin{array}{l}26 \\
22.5 \pm 0.9 \\
1105 \pm 109 \\
2652 \pm 266 \\
43.0 \pm 3.0 \\
111.1 \pm 6.9 \\
23.1 \pm 1.1 \\
1.62 \pm 0.09\end{array}$ & $\begin{array}{l}25 \\
19.2 \pm 0.3 \\
329 \pm 35^{* *} \\
1143 \pm 104^{*} \\
17.4 \pm 1.6^{* *} \\
58.3 \pm 6.3 \\
23.4 \pm 1.3 \\
1.62 \pm 0.07^{* * *}\end{array}$ & $\begin{array}{l}23 \\
19.2 \pm 0.6 \\
592 \pm 61 \\
1579 \pm 184 \\
24.7 \pm 2.6 \\
61.7 \pm 6.7 \\
22.0 \pm 1.1 \\
1.12 \pm 0.07\end{array}$ \\
\hline
\end{tabular}

Males Females
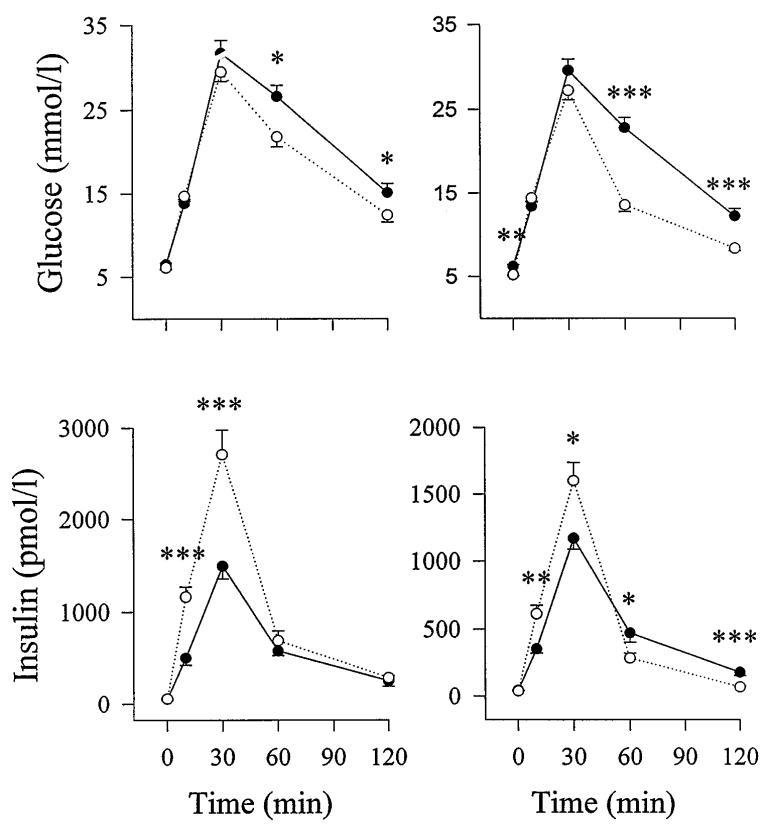

Fig. 2. Plasma glucose and insulin concentrations immediately before and at 10, 30, 60 and $120 \mathrm{~min}$ after gastric gavage of glucose $(150 \mathrm{mg} / \mathrm{mouse})$ in anaesthetized hIAPP transgenic or wild type mice. Means \pm SEM are shown. The numbers of animals in each group were: 24 transgenic males, 26 wild type males, 25 transgenic females and 23 wild type females. The experiments were done when the mice were on average 11 weeks of age (means \pm SD $10.6 \pm 3.8$ weeks of age). Probability level of random difference between the groups; ${ }^{*} p<0.05$, $* * p<0.01, * * * p<0.001 \bullet$ hIAPP transgenic mice, $\bigcirc--\bigcirc$ indicates wild type mice lar peak concentration at $30 \mathrm{~min}$ after glucose was given in hIAPP transgenic compared with wild type animals, both in males and females. Thereafter, the reduction in circulating glucose was retarded in hIAPP transgenic mice, resulting in higher plasma glucose concentrations after 60 and 120 minutes both in males $(p<0.022)$ and in females $(p<0.001)$. Similarly, the $\mathrm{AUC}_{\text {glucose }}$ for the entire 120 min time period was significantly larger in hIAPP transgenic than in wild type mice in both sexes (Table 2). Furthermore, the initial $30 \mathrm{~min}$ increase in circulating insulin was diminished in hIAPP transgenic mice compared with wild type mice, resulting in lower 10 and 30 min concentrations in both males $(p<0.001)$ and females $(p<0.022$; Fig. 2$)$ and lower $\mathrm{AUC}_{\text {insulin }}$ for the 0-30 min time period (Table 2). In contrast, plasma insulin and glucose were higher in hIAPP transgenic females than in wild type mice at 60 and 120 min after gastric glucose had been given. No difference in the variables obtained during the gastric glucose tolerance test was observed between hIAPP transgenic lines no 14 and no 18 (data not shown separately).

Congo red staining of pancreatic sections. Pancreatic sections from all homozygous transgenic mice were evaluated for islet amyloid formation by Congo red staining. No islet amyloid was evident in any of the sections.

\section{Discussion}

Although the physiological function of IAPP has not been established, the peptide is of interest in the 
pathophysiology of Type II diabetes both because it has potential to inhibit insulin secretion and action and it forms fibrils which are constituents of islet amyloid in Type II diabetes [19, 20]. In this study, we have examined the putative physiological importance of IAPP as a circulating substance, by the use of transgenic mice which have considerably increased circulating IAPP concentrations due to beta-cell expression of a hIAPP transgene [21]. We found that this considerable endogenous increase in circulating hIAPP was accompanied by inhibited insulin secretion and impaired glucose elimination after gastric gavage of glucose, both in male and female mice. Since these effects were observed in young mice at an age of two to three months, when islet amyloid is not present, our results are consistent with the notion that endogenous IAPP has the capacity to inhibit insulin secretion and impair glucose elimination after gastric gavage of glucose. Furthermore, since the same effects were observed in hIAPP transgenic mice of two different sublines (no 14 and no 18), it is likely that the effects observed are due to overexpression of hIAPP and the biological action of the peptide, rather than to any effect related to the integration site of the transgene DNA construct in the mouse genomic DNA. In contrast, the beta-cell insulin response to glucose and the glucose elimination after giving glucose intravenously were not different between transgenic and wild type animals. Previous studies in transgenic mice overexpressing hIAPP have found no change in baseline glucose and insulin concentrations [21, 28], hyperglycaemia in the presence of normal insulin concentrations [24] and hyperglycaemia together with hypoinsulinaemia [23]. Since these two latter mouse strains also exhibited concurrent islet amyloidosis [23, 24], our finding of an impairment of the insulin secretory response to gastric glucose concomitantly with glucose intolerance in a transgenic model showing no amyloid formation is the first unambiguous evidence of a metabolic influence of endogenous hIAPP in vivo.

We undertook both intravenous and gastric glucose tolerance tests in our studies. These tests provide different information. The insulin response after the intravenous glucose challenge is a reflection of the direct insulinotropic action of glucose. The response after the gastric challenge depends in addition on the contribution of gastric emptying and glucose absorption rates and to the complex neural and humoral responses elicited by the enteral presentation of glucose. The insulinotropic response to intravenous glucose was not altered in the transgenic mice whereas the response to gastric glucose was reduced. This suggests that the direct insulinotropic action of glucose on the beta cells is not influenced by long-term overexpression of endogenous hIAPP. We first undertook the intravenous glucose tolerance test in 7-week-old mice. Since we did not observe any difference in the variables determined between control and hIAPP transgenic mice, we repeated the intravenous glucose tolerance test in 12-week-old mice, to exclude the similar results in the two groups of animals being due to their young age. There was, however, also at 12 weeks of age, no difference in insulin secretion. The intravenous glucose tolerance test is also used to determine the glucose elimination after giving glucose intravenously although the use of animals that have been fed makes the comparison of beta-cell secretion more reliable than comparison of glucose elimination. We found that glucose elimination after i.v. glucose also was not different between control and hIAPP transgenic mice. These results thus suggest that a considerabe increase of plasma IAPP concentration does not alter glucose-induced insulin secretion or glucose elimination in mice. These conclusions are, however, dependent on the validity of the intravenous glucose tolerance test in mice. The acute increase in plasma insulin after giving glucose rapidly is a reflection of first phase insulin secretion, and therefore yields reliable results on the beta-cell secretion ability. On the other hand, glucose elimination is a net process consisting of both the efficiency of insulin to promote glucose uptake into peripheral tissues and of glucose itself to stimulate glucose uptake of insulin independently, the so-called glucose effectiveness [25]. We show here that the net glucose elimination is not different between the two groups of mice, suggesting, that both insulin sensitivity and glucose effectiveness are unaltered. These two processes underlying glucose elimination might, however, be affected differently from each other [29], and therefore we cannot exclude the possibility that the hIAPP overproducing transgenic mice had opposite effects on insulin sensitivity and glucose effectiveness resulting in an unaltered net glucose elimination. For definite conclusions on insulin sensitivity, hyperinsulinaemic clamp studies are required.

Our results contrast with those of several shortterm studies, showing an inhibitory action of exogenously given IAPP on glucose-stimulated insulin secretion under a variety of experimental conditions $[7-9,11,14,15]$. Instead our data agree with results showing no influence of IAPP on glucose-stimulated insulin secretion $[16,17,30]$. One possible explanation for the failure of hIAPP to inhibit the insulin response to i.v. glucose in our study might be that following the long-term and continuous influence of high concentrations of endogenous hIAPP, any effect of the peptide had vanished due to down regulation of receptors or effector mechanisms. This is indicated by a study showing that an inhibitory action of IAPP on glucose-stimulated insulin secretion fades with time [10]. This possibility is unlikely to explain our results, however, since hIAPP did have effects in the gastric glucose tolerance test, arguing against down regulation of actions. Similarly, a recent report 
showed that glucose-stimulated insulin secretion from islets isolated from 1.5-year-old transgenic mice overexpressing hIAPP was impaired, without any sign of amyloid formation [31], suggesting that at least in some transgenic lines, inhibition of glucosestimulated insulin secretion can occur in vitro after long-term hIAPP overexpression. Our results suggest that endogenous hIAPP does not inhibit glucosestimulated insulin secretion in vivo despite the considerably increased circulating IAPP concentrations. Furthermore, previous in vitro studies on muscle tissue [13] and in vivo studies in rats [14] have indicated that IAPP might impair the peripheral glucose uptake through inhibition of insulin action. In our mice such an action of IAPP is, however, unlikely, considering that the glucose disposal after giving glucose intravenously was not different between wild type and transgenic animals.

In our study, a pronounced inhibitory action of hIAPP was observed on the insulin response to gastric glucose. Furthermore, after gastric glucose, transgenic animals had an impaired ability to eliminate glucose. The impaired glucose elimination possibly reflects the lowered insulin response, since the intravenous glucose tolerance test showed the same ability of wild type and transgenic animals to eliminate an intravenous glucose challenge when the insulin concentrations were the same. This indicates that the influence of IAPP on the complex neural and humoral responses, elicited by the enteral presentation of glucose and of importance for insulin secretion, is more powerful than any direct influence on the beta-cell response to glucose. It is possible that IAPP had impaired the passage of glucose from the gastric lumen to the blood, either through inhibition of gastric emptying or inhibition of glucose absorption, which would be in line with studies in rats and humans [32, 33]. Although we did not specifically examine these processes, this possibility seems unlikely, since the initial 30 min increase in circulating glucose after gastric glucose gavage was not different between wild type and transgenic mice. It could, however, be argued that this same glucose concentration at $30 \mathrm{~min}$ after gastric gavage of glucose occured despite considerably lower insulin concentrations and therefore a higher glucose concentration in transgenic mice would be expected had glucose absorption/gastric emptying not been affected. Therefore, the possibility still exists that the endogenous hyperhIAPPaemia might have impaired gastric emptying/glucose absoprtion in the transgenic mice. Our results would also be explained if IAPP inhibits the secretion or action of gastrointestinal hormones which are released after enteral presentation of glucose and which stimulate insulin secretion, the so-called incretin hormones. Currently, glucagon-like peptide 1 (GLP-1) and gastric inhibitory polypeptide (GIP) are considered the most important incretin hormones [34].
Whether IAPP affects the secretion of GLP-1 or GIP has not yet been examined in mice, due to the lack of assays for determination of these peptides in mouse plasma. The possibility that hIAPP affects the insulinotropic action of the intestinal hormones is supported by a study showing inhibition by IAPP of GLP-1-induced cyclic AMP formation in insulin producing insulinoma cells [35]. Similar studies in vivo, however, are still to be undertaken.

Previous studies in transgenic mice overexpressing hIAPP have shown a pronounced diabetogenic phenotype in the male sex. Male homozygous hIAPP transgenic mice have been found to display hyperglycaemia at the age of 8 weeks, whereas a slight hyperglycaemia was not seen in females until the age of 16 weeks [23]. Similarly, hyperglycaemia has been found to be more common in male than female obese mice overexpressing hIAPP [24]. The mechanisms explaining such sex differences are not known. Our study showed no sex dimorphism in inhibition of insulin secretion and glucose elimination in homozygous hIAPP transgenic non-obese animals aged 2 to 3 months. This suggests a sex difference in the humoral influence of hIAPP is specific for certain genetic backgrounds. Alternatively, it may suggest that it is the formation of islet amyloid, which was not observed in our transgenic mice but was in others, that underlies this sex difference, since islet amyloid in transgenic mice was mainly found in males [23, 24].

In conclusion, our study has shown that transgenic mice overexpressing hIAPP resulting in considerably increased concentrations of IAPP exhibited inhibited insulin secretion and impaired glucose elimination after a gastric glucose challenge. These results are compatible with the notion that hIAPP as a circulating factor has the capacity to inhibit both insulin secretion and glucose elimination with a particular action in the postprandial phase through actions on the gastrointestinal tract or the gut-islet axis or both, which in turn indicates that IAPP could be a diabetogenic factor.

Acknowledgements. The authors are grateful to L. Kvist, L. Bengtsson, U. Gustavsson, G. Graad, E. Dorrestein and T. Hesp for expert technical assistance. The work was supported by grants from the Dutch Diabetes Fund (grant DFN 92.133), Utrecht University Hospital and the Faculty of Medicine, Utrecht University, the Swedish Medical Research Council (grant no 14X-6834), Albert Påhlsson and Novo Nordisk Foundations, Swedish Diabetes Association, Malmö University Hospital and the Faculty of Medicine, Lund University. 


\section{References}

1. Westermark P, Wernstedt C, Wilander E, Hayden DW, O'Brien TD, Johnson KH (1987) Amyloid fibrills in human insulinoma and islets of Langerhans in the diabetic cat are derived from a neuropeptide-like protein also present in normal islet cells. Proc Natl Acad Sci USA 84: 3881-3885

2. Kanatsuka A, Makino H, Ohsawa H et al. (1989) Secretion of islet amyloid polypeptide in response to glucose. FEBS Lett 259: 199-201

3. Lukinius A, Wilander E, Westermark GT, Engström U, Westermark P (1989) Colocalization of islet amyloid polypeptide and insulin in the B cell secretory granules of the human pancreatic islets. Diabetologia 32: 240-244

4. Kahn SE, D'Alessio DA, Schwartz MW et al. (1990) Evidence of cosecretion of islet amyloid polypeptide and insulin by beta cells. Diabetes 39: 634-638

5. Denijn M, De Weger RA, van Mansfeld AD, van Unnik JA, Lips CJ (1992) Islet amyloid polypeptide (IAPP) is synthesized in the islets of Langerhans. Detection of IAPP polypeptide and IAPP mRNA by combined in situ hybridisation and immunohistochemistry in rat pancreas. Histochemistry $97:$ 33-37

6. Ahrén B, Sundler F (1992) Localization of calcitonin generelated peptide and islet amyloid polypeptide in the rat and mouse pancreas. Cell Tissue Res 269: 315-322

7. Degano P, Silvestre RA, Salas M, Peiro E, Marco J (1993) Amylin inhibits glucose-induced insulin secretion in a dose-dependent manner. Study in the perfused rat pancreas. Regul Pept 43: 91-96

8. Ar'Rajab A, Ahrén B (1991) Effects of amidated rat islet amyloid polypeptide on glucose-induced insulin secretion in vivo and in vitro in rats. Eur J Pharmacol 192: 443-445

9. Wagoner PK, Chen C, Worley JF, Dukes ID, Oxford GS (1993) Amylin modulates beta-cell glucose sensing via effects on stimulus-secretion coupling. Proc Natl Acad Sci USA 90: 9145-9149

10. Fürnsinn C, Leuvenink H, Roden M et al. (1994) Islet amyloid polypeptide inhibits insulin secretion in conscious rats. Am J Physiol 267:E300-E305

11. Bretherton-Watt D, Gilbey SG, Ghatei MA, Beacham J, Macrae AD, Bloom SR (1992) Very high concentrations of islet amyloid polypeptide are necessary to alter the insulin response to intravenous glucose in man. J Clin Endocrinol Metab 74: 1032-1035

12. Wang ZL, Bennet WM, Ghatei MA, Byfield PG, Smith DM, Bloom SR (1993) Influence of islet amyloid polypeptide and the 8-37 fragment of islet amyloid polypeptide on insulin release from perifused rat islets. Diabetes 42 : 330-335

13. Leighton B, Cooper GJS (1988) Pancreatic amylin and calcitonin gene-related peptide cause resistance to insulin in skeletal muscle in vitro. Nature 335: 632-635

14. Koopmans SJ, van Mansfeld ADM, Jansz HS (1991) Amylin-induced in vivo insulin resistance in conscious rats: the liver is more sensitive to amylin than peripheral tissues. Diabetologia 34: 218-224

15. Young AA, Rink TJ, Wang MW (1993) Dose-response characteristics for the hyperglycemic, hyperlactemic, hypotensive and hypocalcemic actions of amylin and calcitonin gene-related peptide-I (CGRP- $\alpha)$ in the fasted anesthetized rat. Life Sci 52: 1717-1726

16. Tedstone AE, Nezzer T, Hughes SJ, Clark A, Matthews DR (1990) The effect of islet amyloid polypeptide (amylin) and calcitonin gene-related peptide on glucose removal in the anaesthetized rat and on insulin secretion from rat pancreatic islets in vitro. Biosci Rep 19: 339-345
17. Broderick CL, Brooke GS, DiMarchi RD, Gold G (1991) Human and rat amylin have no effects on insulin secretion in isolated rat pancreatic islets. Biochem Biophys Res Commun 177: 932-938

18. Wilding JP, Khandan Nia N, Bennet WM et al. (1994) Lack of acute effect of amylin (islet associated polypeptide) on insulin sensitivity during hyperinsulinaemic euglycaemic clamp in humans. Diabetologia 37: 166-169

19. Clark A (1992) Islet amyloid: an enigma of type 2 diabetes. Diabetes Metab Rev 8: 117-132

20. Westermark P, Johnson KH, O'Brien TD, Betsholtz C (1992) Islet amyloid polypeptide - a novel controversy in diabetes research. Diabetologia 35: 297-303

21. Höppener JWM, Verbeek JS, de Koning EJP et al. (1993) Chronic overproduction of islet amyloid polypeptide (IAPP)/amylin in transgenic mice: lysosomal localization of human IAPP and lack of marked hyperglycaemia or hyperinsulinaemia. Diabetologia 36: 1258-1265

22. van Hulst KL, Born W, Muff R et al. (1997) Biologically active human islet amyloid polypeptide/amylin in transgenic mice. Eur J Endocrinol 136: 107-113

23. Janson J, Soeller WC, Roche PC et al. (1996) Spontaneous diabetes mellitus in transgenic mice expressing human islet amyloid polypeptide. Proc Natl Acad Sci USA 93: 7283-7288

24. Verchere CB, D'Alessio DA, Palmiter RD et al. (1996) Islet amyloid formation associated with hyperglycemia in transgenic mice with pancreatic beta cell expression of human islet amyloid polypeptide. Proc Natl Acad Sci USA 93: 3492-3496

25. Filipsson K, Pacini G, Scheurink AJW, Ahrén B (1998) PACAP stimulates insulin secretion but inhibits insulin sensitivity in mice. Am J Physiol 274:E834-E842

26. van Hulst KL, Hackeng WHL, Höppener JWM et al. (1994) An improved method for the determination of islet amyloid polypeptide levels in plasma. Ann Clin Biochem 31: $165-170$

27. Putchler H, Sweat F, Levine M (1962) On the binding of Congo red by amyloid. J Histochem Cytochem 10: 355-364

28. Fox N, Schrementi J, Nishi M et al. (1993) Human islet amyloid polypeptide transgenic mice as a model of non-insulin-dependent diabetes mellitus (NIDDM). FEBS Lett 323: 40-44

29. Kahn SE, Bergman RN, Schwartz MW, Taborsky Jr GJ, Porte Jr D (1992) Short-term hyperglycemia and hyperinsulinemia imporove insulin action but do not alter glucose action in normal humans. Am J Physiol 262: E518-E523

30. Inoue K, Hisatomi A, Umeda F, Nawata H (1990) Amylin release from perfused rat pancreas in response to glucose and arginine. Diabetes Res Clin Pract 10: 189-92

31. Tokuyama T, Yagui K, Yamaguchi T et al. (1997) Expression of human islet amyloid polypeptide/amylin impairs insulin secretion in mouse pancreatic $\beta$ cells. Metabolism 46: 1044-1051

32. Young AA, Gedulin BR, Rink TJ (1996) Dose-responses for the slowing of gastric emptying in a rodent model by glucagon-like peptide (7-36) $\mathrm{NH}_{2}$, amylin, cholecystokinin, and other possible regulators of nutrient uptake. Metabolism 45: 1-3

33. MacDonald IA (1997) Amylin and the gastrointestinal tract. Diabet Med 14 [Suppl 2]:S24-S28

34. Thorens B (1995) Glucagon-like peptide-1 and control of insulin secretion. Diabetes Metab 21: 311-318

35. Göke R, McGregor GP, Göke B (1993) Amylin alters the biological action of the incretin hormone GLP1(7-36)amide. Life Sci 53: 1367-1372 